Article

\title{
Biological Hotspot larva Ikan Diperairan Estuari Desa Timbulsoko, Demak
}

\author{
Hanityo Nugroho ${ }^{1, *}$, Sutrisno Anggoro ${ }^{2}$ and Ita Widowati ${ }^{2}$ \\ 1 Faculty of Fisheries and Marine Science, Departement of Marine Science, Master Program, \\ Diponegoro University, Indonesia; hanityonugroho@gmail.com \\ 2 Faculty of Fisheries and Marine Science, Departement of Marine Science, Diponegoro \\ University, Indonesia; mikundip@students.undip.ac.id \\ 2 Faculty of Fisheries and Marine Science, Departement of Marine Science, Diponegoro \\ University, Indonesia; ita_jusup@yahoo.co.id \\ * Correspondence: hanityoadinugroho@students.undip.ac.id
}

\begin{abstract}
Biological Hotspot larva ikan diperairan estusri Desa Timbulsoko, Demak dilakukan pada bulan April-Juni 2019 di Desa Timbulsoko. Timbulsloko memiliki perairan yang subur dikarenakan banyak nelayan yang menjadikan lokasi tersebut sebagai daerah fishing ground. Timbulsloko memiliki potensi untuk menjadi daerah nursery ground dan feeding ground untuk ikan dikarenakan adanya habitat mangrove yang alami akan tetapi bencana abrasi mengakibatkan degradasi habitat nursery ground untuk ikan stadia awal. Hasil penelitian menunjukan Larva ikan yang tertangkap di perairan Desa Timbulsloko terdiri dari 13 famili. Komposisi jenis-jenis larva ikan yang tertangkap adalah Mugilidae, Siganidae, Gobiidae, Leiognathidae, Scatophagidae, Chanidae, Latidae, Engraulidae, Gerreidae, Carangidae, Bagridae, Sillaginidae, Ambassidae. Jenis larva ikan yang paling banyak adalah larva ikan Ambassidae yaitu 46,98\% sedangkan yang paling sedikit tertangkap adalah larva ikan Carangidae, Sillaginidae yaitu sebesar 1,01\%. Kelimpahan larva ikan terbesar adalah 428,271 $\mathrm{ind} / \mathrm{m}^{3}$ terdapat pada titik D2P2, sedangkan kelimpahan larva ikan paling sedikit pada titik NP4 dengan nilai kelimpahan adalah $25,974 \mathrm{ind} / \mathrm{m}^{3}$. Kemiripan nilai ekologis habitat pada titik D2P2 dan A2G1 berdasarkan analisis PCA dan kesamaan kontur dari interpolasi kedalaman secara spasial mengindikasikan adanya jejak biological hotspot di perairan mangrove Desa Timbulsloko sebelum terjadinya bencana abrasi.
\end{abstract}

Keywords: diversity; ecology; fishes; geoscience 


\section{Introduction}

Bioekologi dalam ilmu perikanan mempelajari tentang hubungan ikan dengan lingkungan perairan sebagai habitat alami ikan. Konsep hotspot dalam ilmu perikanan merupakan bagian dari bioekologi itu sendiri, akan tetapi istilah ini lebih dikenal dengan biological hotspot di bidang studi ilmu bumi (geoscience). Biological hotspot merupakan area terkonsentrasinya kehidupan biologis dikarenakan faktor lingkungan, struktur alam dan produktivitas suatu ekosistem [1]. Hotspot merupakan aspek radikal untuk mengidentifikasi daerah konservasi dan strategi manajemen sumberdaya secara spasial. Zona intertidal sebagai daerah pertemuan antara dua ekositem adalah daerah yang produktif sehingga mengakibatkan tingginya keanekaragaman hayati biota, disamping itu resiko kerusakan lingkungan (habitat degradation) juga sangat tinggi dikarenakan interaksi dua ekosistem yang terus terjadi berakibat pada erosi, sedimentasi, eksploitasi, dan sebagainya [2]-[4]. Kajian mendalam untuk daerah ini dinilai sangat penting untuk mencegah kerusakan yang terjadi menimbang tingginya potensi degradasi lingkungan yang disebabkan oleh manusia dan alam. Zona Intertidal desa Timbulsloko mulai mengalami dampak abrasi yang berkembang pesat sejak tahun 2000 disinyalir karena perubahan aliran arus laut akibat pembangunan dan sebagai penahan ombak dan rob yang terjadi di pesisir Kota Semarang (Wetlands, 2016; Hawati et al., 2016; Ismanto et al., 2016). Tujuan dari penelitian ini adalah untuk inventarisasi data ikan stadia awal di perairan Timbulsloko.

\section{Materials and Methods}

Penelitian ini dilakukan di zona intertidal Desa Timbulsloko,Demak. Data primer diperoleh dengan melakukan observasi langsung di lapangan selama bulan April - Juni 2019. Pengumpulan data ikan

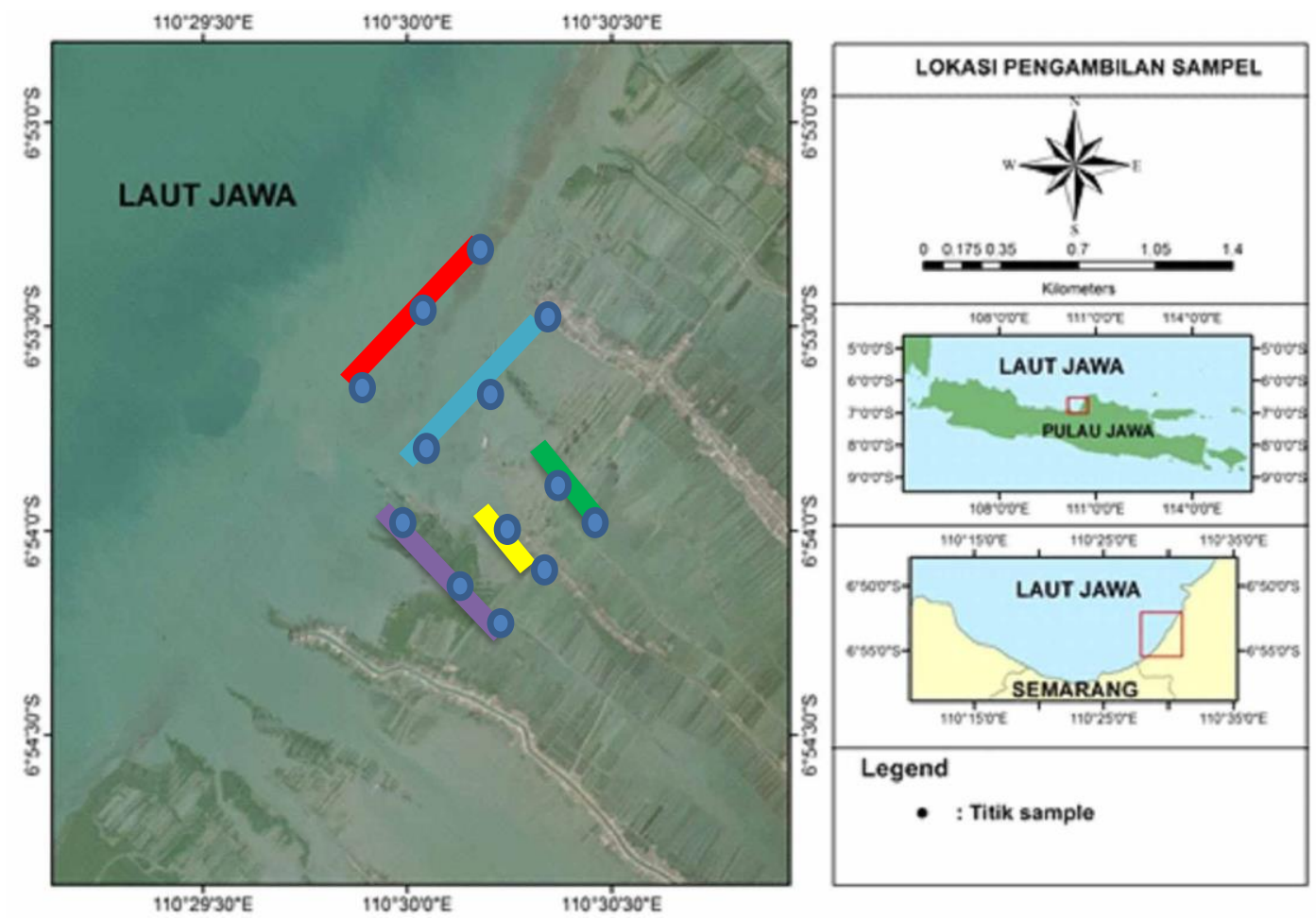

(a) 
Figure 1. Stasiun penelitian pada garis R (Red), LB (Light Blue), P (Purple) : Sungai, Y (Yellow), G (Green) : (a) Lokasi penelitian.

Pengumpulan data ikan stadia awal dilakukan disaat pasang dan surut saat siang hari. Alat yang digunakan untuk menangkap larva ikan yaitu trap net larva ikan dengan ukuran mesh size 0,45 mm diletakan sementara pada area sungai mangrove (mangrove channel).

- Kelimpahan Larva Ikan

Kelimpahan larva ikan yang didefinisikan sebagai banyaknya larva ikan persatuan volume air dihitung dengan menggunakan rumus :

$$
N=n / V_{t s r}
$$

Dimana :

$\mathrm{N}=$ kelimpahan larva ikan (ind $\left./ \mathrm{m}^{3}\right)$

$\mathrm{n}=$ jumlah larva tercacah (ind)

Vtsr $=$ volume air tersaring $(\mathrm{Vtsr}=1 \times \mathrm{t} \times \mathrm{v})$

1 = luas bukaan mulut larva net

$\mathrm{t}=$ lama waktu penarikan (towing time) (menit)

$\mathrm{v}=$ kecepatan waktu penarikan (towing speed) (meter/menit)

- Indeks Keanekaragaman

Indeks keanekaragaman jenis - jenis larva ikan yang tertangkap digunakan untuk mengetahui kehadiran jumlah individu antar genus dalam suatu komunitas. Nilai ini dihitung dengan menggunakan indeks Shannon-Wiener, Formulasi Indeks Keanekaragaman Shannon-Wiener berdasarkan persamaan sebagai berikut :

$$
\mathrm{H}^{\prime}=\sum_{i=1}^{n} \mathrm{pi} \ln \mathrm{pi},
$$

Keterangan :

$\mathrm{H}^{\prime}=$ Indeks Keanekaragaman Shannon-Wiener

$\mathrm{N}=$ jumlah total individu dalam komunitas (ni)

$\mathrm{ni}=$ jumlah individu spesies atau jenis ke-i

$\mathrm{pi}=$ proporsi individu spesies ke-i $(\mathrm{ni} / \mathrm{N})$

$\mathrm{i}=1,2,3, \ldots . ., \mathrm{s}$

$\mathrm{s}=$ jumlah genus/spesies

- Indeks Dominasi

Indeks dominasi untuk mengetahui jenis larva ikan sampel yang dominan, diperoleh dengan menggunakan rumus sebagai berikut (Odum, 1994) :

$$
\mathrm{D}=\sum_{i=1}^{s}(\mathrm{pi})^{2}=\sum_{i=1}^{n}\left(\frac{n i}{N}\right)^{2}
$$

Keterangan :

$\mathrm{D}=$ indeks dominasi

$\mathrm{ni}=$ jumlah individu genus ke- $\mathrm{i}$

$\mathrm{N}=$ jumlah total individu 
$\mathrm{pi}=$ proporsi individu spesies ke-i

$\mathrm{I}=1,2,3, \ldots, \mathrm{s}$

$\mathrm{s}=$ jumlah genus

- Indeks Keseragaman

Keseragaman adalah suatu gambaran tentang sebaran individu dari setiap spesies dalam suatu komintas larva ikan. Nilai indeks keseragaman (E) dihitung berdasarkan persamaan berikut :

$$
E=\frac{\mathrm{H}^{\prime}}{\mathrm{H} \text { maks }} \text { atau } E=\frac{\mathrm{H}^{\prime}}{\ln s},
$$

Keterangan :

$\mathrm{E}=$ indeks keseragaman

$\mathrm{H}^{\prime}=$ indeks keanekaragaman

$\mathrm{s}=$ jumlah genus/spesies

Indeks Keseragaman (E) digunakan untuk mengetahui seberapa besar kesamaan penyebaran jumlah individu dari setiap genus/spesies pada tingkat komunitas. Nilai indeks keseragaman berkisar antara 0-1. Nilai E mendekati 1 apabila sebaran individu antar jenis merata (seragam) sedangkan Nilai E mendekati 0 apabila sebaran individu tidak merata atau ada jenis yang mendominasi.

- Analisa Spasial

Analisa spasial digunakan untuk interpretasi peta biological hotspot larva ikan di perairan Timbulsloko dalam penelitian ini software yang digunakan adalah software QGIS. Biological hotspot larva ikan diketahui dari keterkaitan antara larva ikan dengan parameter oseanografi, kemudian dari nilai struktur komunitasnya (keanekaragaman, dominasi, keseragaman, dan kelimpahan sehingga dapat diketahui daerah pusat sebaran ikan stadia awal di suatu area dalam kisaran suhu, dan salinitas.

- PCA (Principal Component Analysis)

Principal Component Analysis (PCA) secara sederhana dapat diartikan sebagai metode proyeksi untuk mengetahui variabilitas maksimal suatu kelompok data (matriks) [7]. PCA digunakan untuk mencari linear combinations dari parameter lingkungan dan biologi dalam data variasi maksimal atau minimal dengan teknik ordinasi yang memproyeksikan dispersi matriks dari data multidimensi dalam suatu ruang datar. Dengan cara mereduksi ruang maka diperoleh sumbu-sumbu baru yang merepresentasikan secara optimal dari sebagian besar variabilitas data matriks multidimensi sehingga dapat ditemukan hubungan antar ciri dan hubungannya antar obyek. PCA membagi matriks korelasi parameter menjadi beberapa komponen, kemudian menyusun keragaman komponen bersangkutan dari yang terbesar pada sumbu komponen utama hingga didapatkan ditribusi spasial parameter biologi, fisika dan kimia pada suatu daerah tertentu. Korelasi linear antar dua parameter yang dianalisis dari indeks sintetik merupakan peragam dari kedua parameter yang telah dinormalisasikan. Analisis ini digunakan untuk mendeterminasi sebaran parameter bio-fisikakimia perairan [7], [8]. Analisis Komponen Utama menggunakan indeks jarak Euclidean pada data. Jarak Euclidean (Taufik, 2012) hubungan didasarkan pada rumus: 


$$
D^{2}\left(i, i^{\prime}\right)=\Sigma\left(X i j-X i^{\prime} j\right)^{2}
$$

Keterangan :

i, $i^{\prime}=$ dua stasiun (pada baris)

$\mathrm{j}=$ parameter lingkungan

Semakin kecil jarak Euclidean antar 2 stasiun, maka karakteristik bio-fisikakimia antar 2 stasiun tersebut semakin mirip, demikian pula sebaliknya. Perhitungan PCA dilakukan dengan $\begin{array}{lllll}\text { bantuan } & \text { paket } & \text { program } & \text { statistik } & \text { Studio }\end{array}$ (https://www.datacamp.com/community/tutorials/pca-analysis-r).

\section{Results}

\subsection{Larva Ikan Tertangkap}

\subsubsection{Proposi larva ikan}

Larva Ikan yang Tertangkap Komposisi larva ikan yang tertangkap secara keseluruhan berdasarkan pengulangan pengambilan sampel tersaji pada Gambar 3.1.

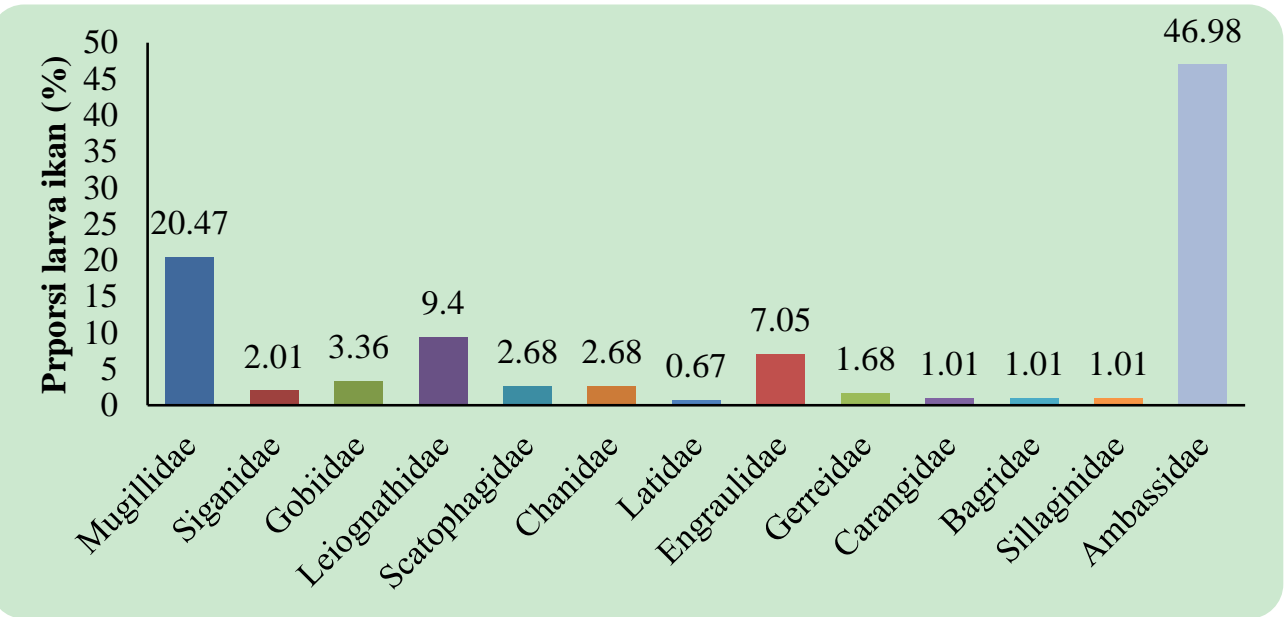

(a)

Figure 2. Komposisi jenis-jenis larva ikan yang tertangkap adalah Mugilidae, Siganidae, Gobiidae, Leiognathidae, Scatophagidae, Chanidae, Latidae, Engraulidae, Gerreidae, Carangidae, Bagridae, Sillaginidae, Ambassidae: (a) Proposi larva ikan (\%).

Larva ikan yang tertangkap di Kawasan Konservasi Mangrove sebanyak ind $/ \mathrm{m}^{3}$ yang terdiri dari 13 famili. Komposisi jenis-jenis larva ikan yang tertangkap adalah Mugilidae, Siganidae, Gobiidae, Leiognathidae, Scatophagidae, Chanidae, Latidae, Engraulidae, Gerreidae, Carangidae, Bagridae, Sillaginidae, Ambassidae. Jenis larva ikan yang paling banyak tertangkap disetiap pengulangan adalah larva ikan Ambassidae. Sedangkan jenis larva ikan yang paling sedikit tertangkap di setiap pengulangan adalah larva ikan Carangidae, Bagridae, Sillaginidae. Persentase kemunculan larva ikan yang sering muncul adalah Mugilidae, Leiognathidae, Ambassidae. Famili Ambassidae tertangkap disetiap titik dengan persentase kemunculan 46,98\%. Larva ikan yang paling jarang muncul yaitu Famili Carangidae, Bagridae, Sillaginidae dengan persentase kemunculan hanya 1,01\%. 
Parameter Fisika-Kimia Perairan yang diukur adalah suhu, pH, salinitas, kecerahan, kedalaman, kecepatan arus. Adapun hasil dari pengukuran Parameter Fisika-Kimia Perairan tersaji dalam Tabel 1.

Table 1. Parameter Fisika-Kimia Perairan.

\begin{tabular}{|c|c|c|c|c|c|c|c|}
\hline \multirow[t]{2}{*}{ No. } & \multirow{2}{*}{$\begin{array}{c}\text { Titik } \\
\text { Sampel }\end{array}$} & \multicolumn{6}{|c|}{ Parameter } \\
\hline & & $\begin{array}{r}\text { Suhu } \\
\left({ }^{0} \mathrm{C}\right)\end{array}$ & Salinitas & Kecerahan & $\begin{array}{c}\text { Kedalaman } \\
(\mathrm{cm})\end{array}$ & $\mathrm{Ph}$ & $\mathrm{DO}$ \\
\hline 1 & A1LB1 & 32,5 & 30 & 6,8 & 45 & 8,23 & 6,9 \\
\hline 2 & J1LB3 & 32,2 & 24 & 34 & 76 & 8,13 & 6,9 \\
\hline 3 & A2G1 & 28,1 & 26 & 17,2 & 17,2 & 7,6 & 7,8 \\
\hline 4 & C1P1 & 29,3 & 28 & 67,8 & 199,6 & 7,14 & 8,4 \\
\hline 5 & $\mathrm{D} 2 \mathrm{P} 2$ & 28,6 & 25 & 33 & 190 & 7,33 & 7,9 \\
\hline 6 & E1P1 & 29,2 & 28 & 52,3 & 117 & 7,46 & 7,4 \\
\hline 7 & E1P1270 & 27,7 & 30 & 31,5 & 242 & 7,92 & 7,6 \\
\hline 8 & C1R1 & 28 & 30 & 42 & 197 & 8,05 & 7,7 \\
\hline 9 & D1R1 & 28,2 & 26 & 90 & 218 & 8,3 & 7,3 \\
\hline 10 & F1R1 & 28 & 28 & 88 & 233,5 & 8,28 & 7,5 \\
\hline 11 & B1R1 & 27,7 & 30 & 38 & 199 & 8,15 & 7,7 \\
\hline 12 & H1Y1 & 29,7 & 31 & 0 & 65 & 8,76 & 7,5 \\
\hline 13 & I1Y1 & 29,1 & 30 & 36,4 & 73 & 8,6 & 7,6 \\
\hline 14 & D1Y1 & 28,4 & 30 & 36,4 & 95 & 8,26 & 8 \\
\hline 15 & NP3 & 30,8 & 28 & 27 & 250 & 8,44 & 7,8 \\
\hline 16 & NP4 & 30,2 & 28 & 18,5 & 57 & 8,39 & 7,4 \\
\hline
\end{tabular}

Nilai rata-rata suhu perairan berkisar antara $27,7-32,5^{\circ} \mathrm{C}$, nilai rata-rata salinitas perairan yang diperoleh adalah 24 - 30\%o, nilai rata-rata kecerahan perairan berkisar antara 0 - 90, nilai rata-rata kedalaman perairan berkisar antara 17,2 - $250 \mathrm{~cm}$, nilai rata-rata $\mathrm{pH}$ perairan berkisar antara 7,33-8,76, nilai rata-rata DO perairan berkisar antara 6,9-8,4. 


\subsection{Struktur Komunitas Larva Ikan}

Struktur komunitas yang dihitung meliputi keanekaragaman $\left(\mathrm{H}^{\prime}\right)$, keseragaman $(\mathrm{E})$, dan dominasi (D). Hasil dari perhitungan nilai indeks keanekaragaman, keseragaman, dan dominasi di perairan Desa Timbulsloko tersaji dalam Tabel 2.

Tabel 2. Struktur Komunitas Larva Ikan di Perairan Desa Timbulsloko

\begin{tabular}{|l|r|r|r|r|}
\hline Stasiun & \multicolumn{1}{|c|}{$\begin{array}{c}\text { Kelimpahan } \\
\text { Larva ikan }\end{array}$} & \multicolumn{1}{c|}{$\begin{array}{c}\text { Indeks } \\
\text { keanekaragaman }\end{array}$} & $\begin{array}{c}\text { Indeks } \\
\text { Dominasi }\end{array}$ & $\begin{array}{c}\text { Index } \\
\text { keseragaman }\end{array}$ \\
\hline A1LB1 & 155.844 & 0.630 & 0.370 & 1.260 \\
\hline J1LB3 & 103.896 & 0.750 & 0.250 & 0.750 \\
\hline A2G1 & 324.675 & 0.633 & 0.367 & 1.003 \\
\hline C1P1 & 194.805 & 0.289 & 0.711 & 0.458 \\
\hline D2P2 & 428.571 & 0.590 & 0.410 & 0.935 \\
\hline E1P1 & 181.818 & 0.856 & 0.144 & 0.856 \\
\hline E1P1270 & 51.948 & 0.319 & 0.681 & 0.639 \\
\hline C1R1 & 116.883 & 0.392 & 0.608 & 0.784 \\
\hline D1R1 & 142.857 & 0.679 & 0.321 & 1.076 \\
\hline F1R1 & 168.831 & 1.138 & 0.138 & 1.138 \\
\hline B1R1 & 116.883 & 0.805 & 0.195 & 0.805 \\
\hline H1Y1 & 90.909 & 0.527 & 0.473 & 0.836 \\
\hline I1Y1 & 155.844 & 0.909 & 0.091 & 0.909 \\
\hline D1Y1 & 168.831 & 0.852 & 0.148 & 0.852 \\
\hline NP3 & 90.909 & 0.679 & 0.321 & 0.679 \\
\hline NP4 & 25.974 & 0.319 & 0.681 & 0.319 \\
\hline
\end{tabular}

Nilai indeks keanekaragaman di setiap titik pengambilan sampel yaitu lebih kecil dari 1 maka tingkat keanekaragamannya rendah. Nilai indeks keseragaman di titik A1LB1 tergolong dalam tingkat keseragaman yang tinggi. Nilai indeks Dominasi tertinggi terletak pada titik C1P1.

\section{Discussion}

Interaksi antara parameter fisika dan biologi mengakibatkan terjadinya distribusi kelimpahan dan keanekaragaman larva ikan di daerah estuari perairan tropis. Diantara variabel lingkungan (salinitas, temperatur, kecerahan, dan DO) dengan keteraturan atau ketidakteraturan pada masing - masing variabel tersebut yang bersifat fluktuatif (selalu berubah dalam setiap waktu), sangat menentukan bagaimana keberlangsungan ekologi di daerah estuari[9], [10]. Adapun perubahan fluktuatif variabel lingkungan pada saat malam dan siang hari memiliki perbedaan seperti pada analisa korelasi Gambar 3. 

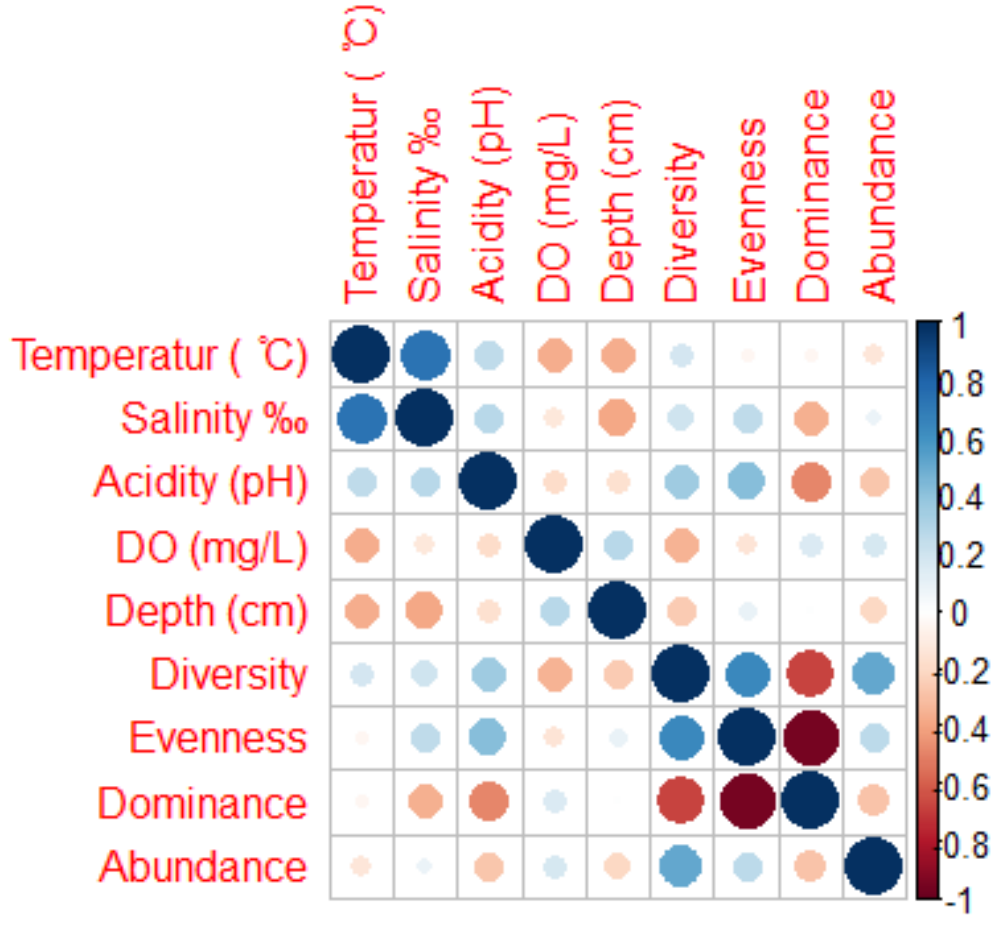

(a)

Figure 3. Hubungan parameter fiska kimia perairan dalam skala nilai 1 hingga - 1: (a) Analisis korelasi menngunakan R Studio [11].

Salinitas dan suhu berkorelasi positif, yaitu ketika salinitas meningkat maka suhu juga meningkat begitupula sebaliknya. Pada variabel yang lain $\mathrm{pH}$ berkorelasi positif terhadap salinitas dan suhu, tetapi memiliki hubungan yang lemah. Indeks keanekaragaman dan keseragaman berkorelasi positif dengan suhu dan salinitas dengan hubungan yang lemah antar variabel. Penelitian ini sesuai dengan penelitian yang pernah dilakukan oleh Hossain et al. (2013), dimana indeks keseragaman dan keanekaragaman memiliki kecenderungan hubungan yang sama. Di sisi lain ditemukan hubungan negatif antara indeks keanekaragaman dan indeks dominasi dalam penelitian ini yang mirip dengan studi muara sungai Naaf oleh[12] . 


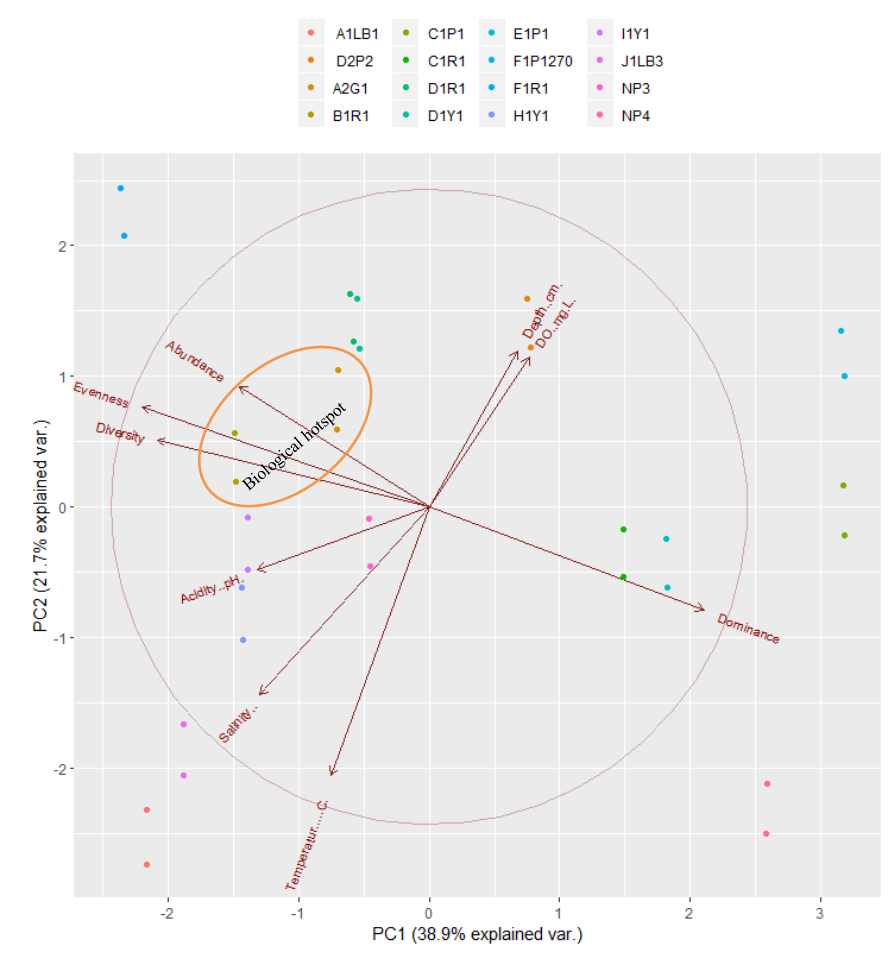

(a)

Figure 4. Jarak euclidean menunjukan kemiripan nilai pada titik D2P2 dan A2G1: (a) Hasil output dari Principal Component Analysis.

Stasiun D2P2 dan A2G1 memiliki kemiripan dimana berdekatan dengan nilai $\mathrm{pH}$, Salinitas, Indeks Keseragaman dan Indeks Keanekaragaman. Hal ini menunjukan bahwa terdapat daerah dengan potensi sebagai daerah preferensi untuk larva ikan bertahan hidup. Selain itu dilihat dari peta kontur kedalaman dan vegetasi secara spasial daerah D2P2 dan A2G1 memiliki kesamaan pola kontur wilayah dan jenis vegetasi yang sama dan terletak pada satu garis lurus yang mengindikasikan adanya pengaruh parameter oseanogarafi dalam menentukan biological hotspot larva ikan. Kemiripan ekologi tersebut juga dapat menjelaskan jejak kesuburan habitat mangrove sebelum bencana abrasi di Desa Timbulsloko. 


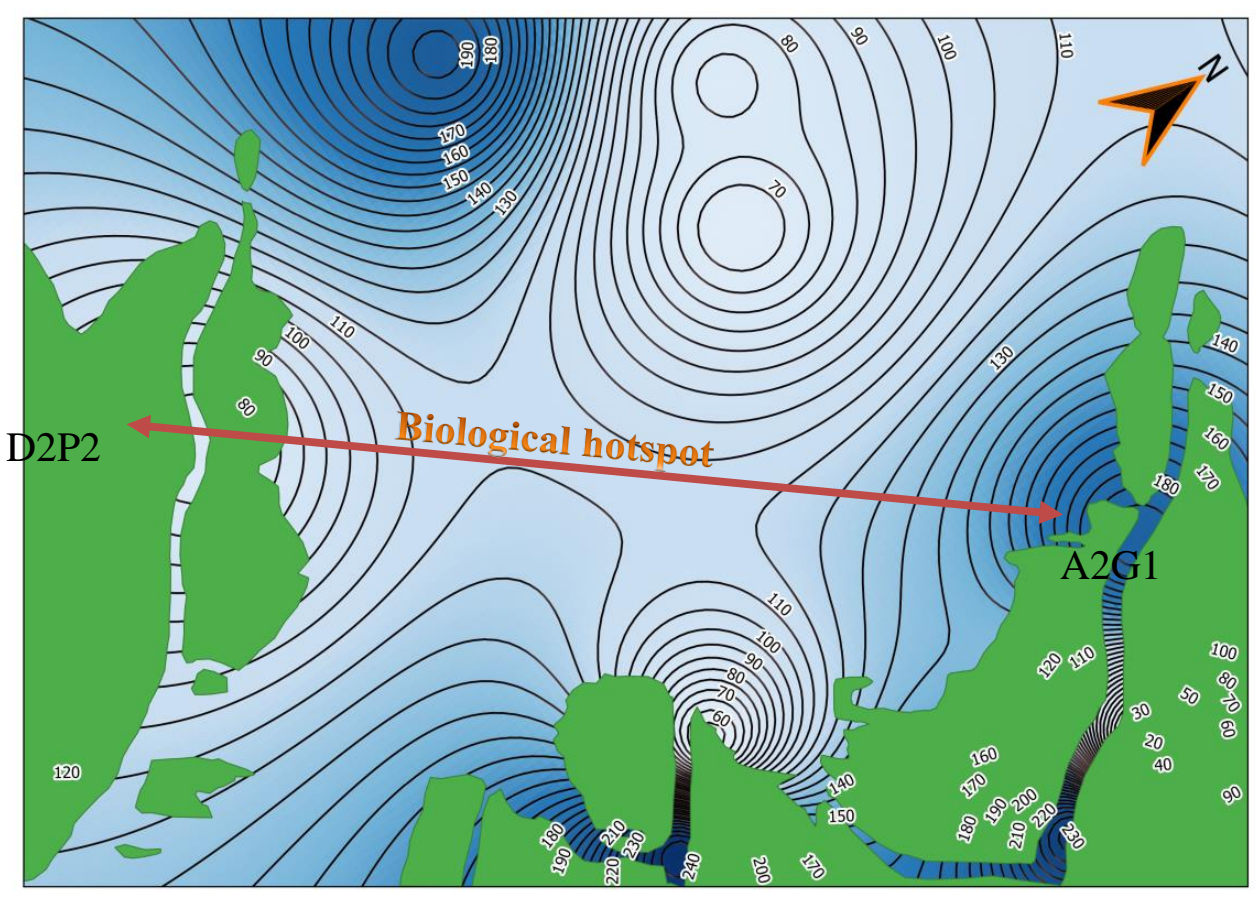

Figure 5. Perkiraan lokasi biological hotspot.

\section{Conclusions}

Kemiripan nilai ekologis habitat pada titik D2P2 dan A2G1 berdasarkan analisis PCA dan kesamaan kontur dari interpolasi kedalaman secara spasial mengindikasikan adanya jejak biological hotspot di perairan mangrove Desa Timbulsloko sebelum terjadinya bencana abrasi.

\section{References}

[1] P. Petitgas, M. Woillez, M. Doray, and J. Rivoirard, "A Geostatistical Definition of Hotspots for Fish Spatial Distributions," Math. Geosci., pp. 65-77, 2016.

[2] R. Vinícius, S. Santos, S. Ramos, A. Cristina, and T. Bonecker, “Environmental control on larval stages of fish subject to specific salinity range in tropical estuaries," Reg. Stud. Mar. Sci., 2017.

[3] M. Huxham, E. Kimani, and J. Augley, "Mangrove fish: A comparison of community structure between forested and cleared habitats," vol. 60, pp. 637-647, 2004.

[4] C. T. Perry and A. Berkeley, "Intertidal substrate modification as a result of mangrove planting: Impacts of introduced mangrove species on sediment microfacies characteristics," Estuar. Coast. Shelf Sci., vol. 81, no. 2, pp. 225-237, 2009.

[5] Hawati et al, "Waves Induce Sediment Transport at Coastal Region of Timbulsloko Demak," Earth Environ. Sci., vol. 55, 2017.

[6] A. Ismanto, M. Zainuri, S. Hutabarat, and D. N. Sugianto, "Sediment Transport Model In Sayung District, Demak," vol. 012007, pp. 3-9.

[7] K. Kafadar, J. R. Koehler, W. N. Venables, and B. D. Ripley, "Modern Applied Statistics with S-Plus," Am. Stat., vol. 53, no. 1, p. 86, 2006.

[8] M. Taufik, "PERAIRAN LAGUNA PULAU PARI DAN SEKITARNYA," 2012.

[9] S. J. M. Blaber, Tropical Estuarine Fishes. .

[10] A. K. Whitfield, "Ichthyofaunal assemblages in estuaries: A South African case study," pp. 151-186, 
72

73

74

75

76

77

78

79

1999.

[11] M. Friendly, "Corrgrams: Exploratory displays for correlatigon matrices," Am. Stat., vol. 56, no. 4, pp. 316-324, 2002.

[12] M. S. Hossain, N. G. Das, S. Sarker, and M. Z. Rahaman, "Fish diversity and habitat relationship with environmental variables at Meghna river estuary , Bangladesh," Egypt. J. Aquat. Res., vol. 38, no. 3, pp. 213-226, 2013.

(C) 2019 by the authors. Submitted for possible open access publication under the terms and conditions of the Creative Commons Attribution (CC BY) license (http://creativecommons.org/licenses/by/4.0/). 